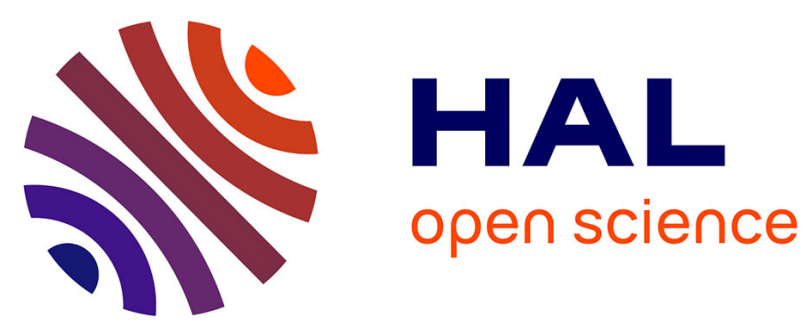

\title{
The first amber stenophlebiid damsel-dragonfly (Odonata, Epiproctophora, Stenophlebiidae) from mid-Cretaceous amber of northern Myanmar
}

Diying Huang, Yanzhe Fu, André Nel

\section{- To cite this version:}

Diying Huang, Yanzhe Fu, André Nel. The first amber stenophlebiid damsel-dragonfly (Odonata, Epiproctophora, Stenophlebiidae) from mid-Cretaceous amber of northern Myanmar. Cretaceous Research, 2019, 94, pp.40-44. 10.1016/j.cretres.2018.10.008 . hal-01980235

\section{HAL Id: hal-01980235 \\ https: / hal.sorbonne-universite.fr/hal-01980235}

Submitted on 18 Jan 2019

HAL is a multi-disciplinary open access archive for the deposit and dissemination of scientific research documents, whether they are published or not. The documents may come from teaching and research institutions in France or abroad, or from public or private research centers.
L'archive ouverte pluridisciplinaire HAL, est destinée au dépôt et à la diffusion de documents scientifiques de niveau recherche, publiés ou non, émanant des établissements d'enseignement et de recherche français ou étrangers, des laboratoires publics ou privés. 
1 The first amber stenophlebiid damsel-dragonfly (Odonata, Epiproctophora,

2 Stenophlebiidae) from mid-Cretaceous amber of northern Myanmar

3

4 Diying Huang ${ }^{\mathrm{a}}$, Yanzhe Fu ${ }^{\mathrm{b}}$, André $\mathrm{Nel}^{\mathrm{c}}$

5 Sciences, Nanjing 210008, PR China

\section{ABSTRACT}

\section{Introduction}

a State Key Laboratory of Palaeobiology and Stratigraphy, Center for Excellence in Life and Paleoenvironment, Nanjing Institute of Geology and Palaeontology, Chinese Academy of

b University of Science and Technology of China, Hefei 230026, PR China

c Institut Systématique Evolution Biodiversité (ISYEB), Muséum national d'Histoire naturelle, CNRS, Sorbonne Université, EPHE, 57 rue Cuvier, CP 50, 75005 Paris, France

Burmastenophlebia flecki gen. et sp. nov., first stenophlebiid damsel-dragonfly in midCretaceous Burmese amber is described and illustrated. It allows to show structures proper to this family, previously unknown. In particular, the subnodus is enforced by a dorsal chitinous bracket and the nodal furrow is very weak, suggesting that the stenophlebiid nodal complex is very particular and did not functioned as in other Odonata.

Keywords: Insecta; Odonata; Stenophlebiidae; Burmese amber; gen. et sp. nov.

Burmese amber is currently the most important source of knowledge on the insects from the mid-Cretaceous. It is especially the case for the Odonata (for a catalogue of described inclusions in this amber see Ross, 2018). The Zygoptera clearly dominate this assemblage, probably in 
part because of their smaller sizes and lower capacities to escape the fresh resin than the larger and stronger Anisoptera. Few more 'basal' Epiproctophora (former 'Anisozygoptera' or damsel-dragonflies are also recorded, viz. the Epiophlebioidea Burmaphlebiidae (Bechly and Poinar, 2013). The discovery of any new taxon of this clade in this amber is of interest because they can give new characters not observable in the numerous Mesozoic Epiproctophora preserved as compression fossils. Among these, the Stenophlebioptera are especially important because they are currently considered as the sister group of the Pananisoptera (Bechly, 2016), but up to now no fossil stenophlebioid in amber has been recorded. This clade is strictly Mesozoic but it was clearly widespread in the Jurassic of Europe and Asia, and the Lower Cretaceous of Europe, Asia, and Brazil. Here we describe the first Stenophlebiidae from the mid-Cretaceous Burmese amber. Although incomplete, the fossil shows some wing structures that were unknown.

\section{Material and methods}

The amber containing the damselfly was collected in the Hukawng Valley $\left(26^{\circ} 29^{\prime} \mathrm{N}, 96^{\circ} 35^{\prime}\right.$ E) of Kachin Province, Myanmar (locality in Kania et al., 2015: fig. 1). The re-deposition age of Burmese amber was considered to be $98.79 \pm 0.62 \mathrm{Ma}$ (Shi et al., 2012), but palynology and an ammonite from the amber-bearing layers suggest a late Albian age (Cruickshank and Ko, 2003) which we adopt herein. The amber containing the damselfly is yellow and transparent. The individual shows a nearly complete fore wing (basal section missing) and fragments of a hind wing, of thorax, a complete fore leg, a nearly complete middle leg, and two incomplete hind legs. Photographs were taken using a Zeiss Discovery V20 microscope system. Photomicrographs with a green or red backgrounds were taken using fluorescence as a light source attached to the Zeiss Axio Imager 2 light microscope. Six small neuropterans, two beetles, one dipteran, one psocopteran wing, and one spider co-occurred with this damsel- 
dragonfly. The specimen is housed in the Nanjing Institute of Geology and Palaeontology, Chinese Academy of Sciences, China. All taxonomic acts established in the present work have been registered in Zoo-Bank (see below), together with the electronic publication LSID: $x x x x$ We follow the wing venation nomenclature of Riek and Kukalová-Peck (1984), amended by Nel et al. (1993) and Bechly (1996). The higher classification of fossil and extant Odonatoptera, as well as familial and generic characters followed in the present work are based on the phylogenetic system proposed by Bechly $(1996,2016)$ and Fleck et al. (2003) for the revision of the Stenophlebioptera. Abbreviations for wing venation are as follow: IR = intercalary radial vein; $\mathrm{MA}=$ media anterior; $\mathrm{MP}=$ media posterior; $\mathrm{N}=$ nodus $; \mathrm{Cr}=$ nodal crossing; $\mathrm{Pt}=$ pterostigma; $\mathrm{RP}=$ radius posterior; $\mathrm{ScP}=$ subcostal posterior; $\mathrm{Sn}=$ subnodus .

\section{Systematic Palaeontology}

Order Odonata Fabricius, 1793

Infrasuperorder Stenophlebioptera Bechly, 1996

Superfamily Stenophlebioidea Pritykina, 1968

Family Stenophlebiidae Needham, 1903

Genus Burmastenophlebia gen. nov.

(urn:lsid:zoobank.org:act:E656B6E7-3F01-46E5-9165-64A0DB80BC08)

Type species: Burmastenophlebia flecki sp. nov.

Etymology. Named after Burma, ancient name for Myanmar, and Stenophlebia.

Diagnosis. Wing venation characters only. No secondary longitudinal vein just basal of base of RP2, between RP1/2 and IR2; pterostigma covering two cells and a half, nodal Cr receiving one postnodal crossvein and one antenodal crossvein, subnodus receiving no antesubnodal crossveins; IR1 basally quite straight; three antenodal crossveins of first row between nodus 
and level of base of RP3/4; a straight Mspl; a straight supplementary longitudinal vein of postdiscoidal space.

\section{Burmastenophlebia flecki sp. nov.}

(urn:1sid:zoobank.org:act:128A9528-0465-45BE-8E94-6AA989E5CFE3)

Fig. 1

Diagnosis. Ratio length/width of pterostigma $=5$; wing $5.7 \mathrm{~mm}$ wide, rather small. Burmastenophlebia flecki is among the smallest Stenophlebiidae, its wing dimensions being comparable to those of Gallostenophlebia incompleta Nel et al., 2015.

Etymology. Named after Dr. Günther Fleck, for his numerous contributions to Odonatology. Holotype. NIGP168834, Nanjing Institute of Geology and Paleontology, Chinese Academy of Sciences, China.

Locality and Horizon. Hukawng Valley, Kachin Province, Myanmar; late Albian, late Lower Cretaceous.

Description. Four legs (two hind legs are incomplete), a fragment of the base of the abdomen and posterior part of thorax and two incomplete wings with base missing; three pair of legs very similar in shape and size; fore coxae rather small, trochanter thin, femora (3.0 mm long) slightly longer than tibia, almost straight, slightly protruding at median section, armed with two series of moderately long, asymmetric ventral spines, spines of one side obviously larger than those of the other side, sizes of spines increasing from basal section to middle and posterior sections, several long spines alternatively arranged with short spines in distal third; tibia (2.9 mm long) armed with two series of spines, nearly symmetrical, spines of median section larger than basal and distal spines, long spines and short spines alternatively arranged in one side only; tarsi $(0.7$ mm long) three-segmented, armed with two series of spines, each tarsomere armed with two spines in one side, the basal one distinctly smaller than distal one, first tarsomere short and 
oblique apically, third tarsomere longer than second one; tarsal claws moderately large, curved and sharp, with a tiny tooth near apex; middle femora (4.0 mm long) distinctly longer than tibia, clearly protruding at median section, long and short ventral spines alternatively arranged in basal section, long spines rather sparse in middle and distal sections, characters of tibia and tarsi similar to those of fore legs, middle tibia (2.7 mm long) slightly shorter than fore tibia, middle tarsi $0.7 \mathrm{~mm}$ long; hind femora $(5.0 \mathrm{~mm}$ long) nearly straight, distinct longer than middle femora, two series of spines nearly symmetrical, long and short ventral spines alternatively arranged, longest spines in middle section, rather sparse in distal section; the basal two abdominal segments are preserved, no trace of secondary genital structures on segment 2 ; length of preserved part of wing $22.6 \mathrm{~mm}$; wing ca. $30-33 \mathrm{~mm}$ long, width $5.7 \mathrm{~mm}$; pterostigma 2.5 $\mathrm{mm}$ long, $0.5 \mathrm{~mm}$ wide; covering two cells and a half; pterostigmal ornamentation apparently wrinkled-like (sensu Bechly, 1996); basal side of pterostigma with a crossvein ending in it, and much more oblique than distal side; no pterostigmal brace; a vein Mspl and a long secondary longitudinal convex vein in postdiscoidal area beginning near or on MAb; vein ScP clearly fused with costal margin; nodal furrow very weak; nearly no interruption of costal margin; vein Cr very oblique and directly aligned with general trend of ScP; one postnodal crossvein and one antenodal crossvein of second row reaching $\mathrm{Cr}$; subnodus ( $\mathrm{Sn})$ very oblique and aligned with $\mathrm{Cr}$, with no crossvein reaching it; base of RP2 slightly distal to $\mathrm{Sn}$; no secondary longitudinal 'stenophlebiid veinlet' between RP1+2 and IR2 below subnodus; antenodal area only partly preserved; primary antenodal cross-vein Ax1 and Ax2 not preserved, 10 secondaries between $\mathrm{C}$ and ScP not aligned with the 10 preserved antenodal crossveins of second row between ScP and RA; 20 postnodal crossveins, not aligned with the 15 postsubnodals; bases of RP3/4 and IR2 close together, between nodus and arculus, probably closer to nodus (only three cells basal to nodus) than to arculus; a very long and narrow bridge space; oblique vein "O" absent; IR1 well defined, straight and proximally parallel to RA; numerous secondary 
longitudinal veins between the main veins; all longitudinal veins curved near posterior wing margin; veins with fine and short spines.

\section{Discussion}

This fossil is attributable to the Stenophlebiidae because of the following synapomorphies (Fleck et al., 2003): IR2 and RP3/4 arising close together; a very long and narrow bridge space; a long and not zigzagged (or slightly zigzagged) secondary longitudinal convex vein in postdiscoidal area, parallel to MP, its base being close to discoidal triangle; a long and not zigzagged concave Mspl; wings elongate and slender; nodal veinlet extremely oblique and very long; nodal furrow reduced; numerous intercalary veins with a characteristic pattern between MA and MP (described in Fleck et al., 2003); presence of numerous antenodal crossveins distal of Ax2.

The Stenophlebioptera Bechly, 1996 comprise some other families: affinities with the Liassostenophlebiidae Fleck et al., 2003 are excluded because of the absence of the oblique vein 'O', the long pterostigma, the long and straight IR1, and the long convex secondary longitudinal vein in postdiscoidal area. The presence of numerous secondary antenodal crossveins of first row distal of $\mathrm{Ax} 2$, the long nodal $\mathrm{Cr}$ and subnodus exclude affinities with the Prostenophlebiidae Fleck et al., 2003. Bechly $(1996,2016)$ included the Gondwanogomphidae Bechly, 1996 in the Stenophlebioptera, but Fleck et al. (2003) discussed this hypothesis and considered it as weakly supported. Burmastenophlebia gen. nov. is definitely not related to Gondwanogomphus Schlüter and Hartung, 1982.

Among the Stenophlebiidae, Burmastenophlebia differs from Yixianstenophlebia Nel and Huang, 2015, Stenophlebia Hagen, 1866, Hispanostenophlebia Fleck et al., 2003, Sinostenophlebia Hong, 1984, and Gallostenophlebia Nel et al., 2015 in the absence of a secondary longitudinal vein just basal of base of RP2, between RP1/2 and IR2 (Fleck et al., 2003; Bechly et al., 2003; Nel et al., 2015; Nel and Huang, 2015; Zheng et al., 2016a,b). 
152 secondary longitudinal vein. The pterostigmata of Cratostenophlebia and Cretastenophlebia cover much more cells than in Burmastenophlebia, their nodal Cr receive several antenodal and postnodal crossveins, their subnodus receive two antesubnodal crossveins, and the IR1 of Cretastenophlebia is basally zigzagged instead of being quite straight in Burmastenophlebia (Fleck et al., 2003; Bechly, 2007; Zheng et al., 2018). Mesostenophlebia has 11 antenodal crossveins of first row between the nodus and the level of the base of RP3/4, instead of only three in Burmastenophlebia (Fleck et al., 2003). Burmastenophlebia is difficult to compare to Liaostenophlebia Zheng et al., 2016 because there are very few comparable preserved parts (Burmastenophlebia is known by distal wing structures, while Liaostenophlebia is known by basal structures). Nevertheless, Burmastenophlebia has straight Mspl and supplementary longitudinal vein of postdiscoidal space while these veins are slightly zigzagged in Liaostenophlebia (Zheng et al., 2016a).

\section{Concluding remarks}

This fossil is the first amber record of the clade Stenophlebioptera. Thus it is of interest for some morphological structures not discernable in compression fossils. In particular, the subnodus of Burmastenophlebia is enforced by a dorsal chitinous bracket and the nodal furrow is very weak, suggesting that the stenophlebiid nodal complex is very particular and did not functioned as in other Odonata. Possibly the nodus of Burmastenophlebia could not be bent as in modern Libellulidae (Fauziyah et al., 2014), and the nodal $\mathrm{Cr}$ and subnodus had a more important function in the strengthening of the whole nodal complex than in other Odonata.

Burmastenophlebia has long 'L spines' on the main veins and crossveins in dorsal view but no 'S spine' is visible on the veins. The spines of the costal edge are looking like those of an Anisoptera Petaluridae, viz. long scale-like structures separated by indentations of the margin 
(see Bechly, 1996: 303, fig. 54). This character would support the current attribution of the

177 Stenophlebioptera as sister-group of the Pananisoptera (Bechly, 2016).

178

179

The Stenophlebiidae were clearly widespread during the Lower Cretaceous, as they have been found in Brazil, Europe, and Central Asia. The region of Myanmar was probably an island during the mid-Cretaceous, period of deposition of the Burmese amber (Rasnitsyn and ÖhmKühnle, 2018). This island separated from the Gondwana during the Lower Cretaceous. This is congruent with the presence of the Stenophlebiidae in the central part of Gondwana (Brazil) during the Aptian. The Stenophlebiidae were probably present also in Africa at that time but they remain to be found. The whole clade was no longer recorded after the Cenomanian.

\section{Acknowledgements}

This project was supported by the Strategic Priority Research Program of Chinese Academy of Sciences, Grant No. XDB26000000 and XDB18000000, and National Natural Science Foundation of China (41688103).

\section{References}

Bechly, G., 1996. Morphologische Untersuchungen am Flügelgeäder der rezenten Libellen und deren Stammgruppenvertreter (Insecta; Pterygota; Odonata), unter besonderer Berücksichtigung der Phylogenetischen Systematik und des Grundplanes der Odonata. Petalura Special Volume 2, 1-402.

Bechly, G., 2007. Chapter 11.5 Odonata: damselflies and dragonflies. pp. 184-222. In: Martill, D., Bechly, G., Loveridge, R., (eds). The Crato fossil beds of Brazil: Window into an ancient world. Cambridge University Press, Cambridge: 624 pp.

Bechly, G. 2016. Phylogenetic systematics of Odonata. - homepage on Internet site: https://bechly.lima-city.de/phylosys.htm 
Bechly, G., Dietl, G., Schweigert, G., 2003. A new species of Stenophlebia (Insecta: Odonata: Stenophlebiidae) from the Nusplingen Lithographic Limestone (Upper Jurassic, SW Germany). Stuttgarter Beiträge zur Naturkunde (B) 338, 1-10.

Bechly, G., Poinar, G.O.Jr., 2013. Burmaphlebia reifi gen. et sp. nov., the first anisozygopteran damsel-dragonfly (Odonata: Epiophlebioptera: Burmaphlebiidae fam. nov.) from Early Cretaceous Burmese amber. Historical Biology, an International Journal of Paleobiology 25, $233-237$.

Cruickshank, R.D., Ko, K., 2003. Geology of an amber locality in the Hukawng Valley, northern Myanmar. Journal of Asian Earth Sciences 21, 441-455.

Fauziyah, S., Alam, C., Soesilohadi, R.C.H., Retnoaji, B., Alam, P., 2014. Morphological and mechanical characterisation of the hindwing nodus from the Libellulidae family of dragonfly (Indonesia). Arthropod Structure \& Development 43, 415-422.

Fleck, G., Bechly, G., Martínez-Delclòs, X., Jarzembowski, E.A., Coram, R., Nel, A., 2003. Phylogeny and classification of the Stenophlebioptera (Odonata, Epiproctophora). Annales de la Société Entomologique de France (N.S.) 39, 55-93.

Kania, I., Wang, B., Szwedo, J., 2015. Dicranoptycha Osten Sacken, 1860 (Diptera, Limoniidae) from the earliest Upper Cretaceous Burmese amber. Cretaceous Research 52, 522530.

Nel, A., Fleck, G., Garcia, G., Gomez, B., Ferchaud, P., Valentin, X., 2015. New dragonflies from the lower Cenomanian of France enlighten the timing of the odonatan turnover at the Early

221 - Late Cretaceous boundary. Cretaceous Research 52, 108-117.

222 Nel, A., Huang, Di-ying, 2015. A new genus and species of damsel-dragonfly (Odonata:

223 Stenophlebiidae) from the Lower Cretaceous of Inner Mongolia, China. Cretaceous Research $56,421-425$. 
Nel, A., Martínez-Delclòs, X., Paicheler, J.-C., Henrotay, M., 1993. Les 'Anisozygoptera' fossiles. Phylogénie et classification (Odonata). Martinia Numéro Hors Série 3, 1-311.

227

Rasnitsyn, A.P., Öhm-Kühnle, C., 2018. Three new female Aptenoperissus from midCretaceous Burmese amber (Hymenoptera, Stephanoidea, Aptenoperissidae): unexpected diversity of paradoxical wasps suggests insular features of source biome. Cretaceous Research $91,168-175$.

Riek, E.F., Kukalová-Peck, J., 1984. A new interpretation of dragonfly wing venation based upon Early Carboniferous fossils from Argentina (Insecta: Odonatoidea) and basic characters states in pterygote wings. Canadian Journal of Zoology 62, 1150-1166.

Ross, A.J. 2018. Burmese (Myanmar) amber taxa, on-line checklist v.2017.4

Shi, G., Grimaldi, D.A., Harlow, G.E.,Wang, J., Wang, J.,Wang, M., Lei,W., Li, Q., Li, X., 2012. Age constraint on Burmese amber based on U-Pb dating of zircons. Cretaceous Research $37,155-163$.

Zheng, Daran, Nel, A., Wang, Bo, Jarzembowski, E.A., Chang, Su-Chin, Zhang, Haichun, 2016a. The first Early Cretaceous damsel-dragonfly (Odonata: Stenophlebiidae: Stenophlebia) from western Liaoning, China. Cretaceous Research 61, 124-128.

Zheng, Daran, Wang, He, Jarzembowski, E.A., Wang, Bo, Chang, Su-Chin, Zhang, Haichun, 2016b. New data on Early Cretaceous odonatans (Stenophlebiidae, Aeschnidiidae) from northern China. Cretaceous Research 67, 59-65.

Zheng, Daran, Zhang, Haichun, Wang, Bo, Chang, Su-Chin, 2018. A new species of damseldragonfly (Odonata: Stenophlebiidae: Cretastenophlebia) from the Lower Cretaceous of the Jiuquan Basin, northwestern China. Earth and Environmental Science Transactions of the Royal Society of Edinburgh 107, 185-189. 
249 Fig. 1. Burmastenophlebia flecki gen. et sp. nov. Holotype NIGP168834. a, general view of 250 wing; b, mid part of wing; c, pterostigmal region; d, wing base, legs and body fragments; e, 251 general view of amber piece, $\mathrm{f}$, middle tarsi with arrow indicating the joints under fluorescence 252 light; g, detail of nodus under fluorescence light; h, pterostigma under fluorescence light. Scale 253 bars $=2.0 \mathrm{~mm}(\mathrm{a}, \mathrm{e}), 1 \mathrm{~mm}(\mathrm{~b}, \mathrm{c}, \mathrm{d}), 0.5 \mathrm{~mm}(\mathrm{~g}, \mathrm{~h}), 0.2 \mathrm{~mm}(\mathrm{f})$. 
